УДК 544.16; 674.032.475.3

\title{
НАТУРАЛЬНЫЕ ПРОДУКТЫ И ИХ ПРОИЗВОДНЫЕ, ПОЛУЧАЕМЫЕ ПО ТЕХНОЛОГИИ ЗАМКНУТОГО ЦИКЛА ПЕРЕРАБОТКИ БИОМАССЫ ЛИСТВЕННИЦЫ СИБИРСКОЙ
}

\author{
(C) В.А. Бабкин ${ }^{1}$, Л.А. Остроухова ${ }^{1 *}$, Л.И. Копьлова ${ }^{2}$
}

\author{
${ }^{1}$ Иркутский институт химии им. А.Е. Фаворского СО РАН, ул. Фаворского, 1, \\ Иркутск, 664033 (Россия), e-mail: babkin@ irioch.irk.ru \\ ${ }^{2}$ Иркутский государственный университет, педагогический институт, \\ ул. Нижняя Набережная, 6, Иркутск, 664003 (Россия)
}

Описан новый подход к технологии комплексной переработки биомассы хвойных пород деревьев на примере лиственницы сибирской, полностью исключающий наличие отходов производства. Охарактеризованы свойства всех получаемых продуктов и области их применения. Приведены новые данные по биологической активности основных продуктов на базе экстрактивных веществ биомассы лиственницы. Описаны возможности их практического применения в медицине и сельском хозяйстве.

Исследования направлены на создание технологии переработки биомассы лиственницы по принципу замкнутого цикла. Технология непрерывна и предполагает использование в качестве сырья каждого цикла остаток предыдущего без выгрузки из экстрактора. Процесс проводится в одном экстракторе до полного использования исходной технологической щепы.

Рассмотрен вопрос о важности определения необходимых параметров технологии для получения оптимального количества дигидрокверцетина (ДКВ) с максимальным содержанием оптического изомера (транс $(+)-2 R 3 R$-изомер), обладающего наибольшей биологической активностью.

Описана протективная активность ДКВ при экспериментальной гриппозной инфекции, вызванной вирусом гриппа различных типов, и новые исследования в отношении энтеровирусов. Рассмотрена биологическая активность полисахарида из лиственницы арабиногалактана (АГ), новые аспекты его применения в медицине и сельском хозяйстве.

Определены практически значимые биологически активные продукты из коры лиственницы, показано их значение для медицины и народного хозяйства России.

Ключевые слова: древесина лиственницы, экстракция, дигидрокверцетин, стереоизомеры, энтеровирус, арабиногалактан, пребиотик, терпеноиды.

\section{Введение}

Запасы древесины хвойных пород Сибири (сосна, ель) вокруг крупнейших целлюлозно-бумажных предприятий (Братский ПК, Усть-илимский ЦБК) в основном практически исчерпаны или вывезены в Китай. Остались громадные запасы биомассы лиственницы, которые могут быть переработаны по созданной в лаборатории химии древесины Иркутского института химии им. А.Е.Фаворского СО РАН нетрадиционной технологии замкнутого цикла. Данная технология предполагает использовать все части дерева, включая корни, ствол, кору и сучки.

Бабкин Василий Анатольевич - заведующий лабораторией химии древесины, доктор химических наук, профессор, e-mail: babkin@irioch.irk.ru

Остроухова Людмила Андреевна - старший научный сотрудник лаборатории химии древесины, кандидат химических наук, e-mail: 1-ostrouhova@yandex.ru Копылова Лириса Ивановна - профессор кафедры естественно-научных дисциплин, доктор химических наук, e-mail:1kopylova@mail.ru
В результате такой переработки утилизируются все классы экстрактивных соединений дерева: флавоноиды, терпеноиды, лигнаны, фенолокислоты, полисахариды, пектины, дубильные вещества и лигнин. Все полученные вещества предполагается использовать для получения медицинских и ветеринарных препаратов, функциональной пищи, для производства косметических средств и стимулято-

\footnotetext{
* Автор, с которым следует вести переписку.
} 
ров роста растений. Исследования лаборатории направлены на создание технологии переработки биомассы лиственницы по принципу замкнутого цикла, предполагающего использование в качестве сырья каждого цикла остаток предыдущего цикла без выгрузки из экстрактора. Процесс проводится в одном экстракторе до полного использования исходной технологической щепы. При создании такой технологии особое внимание уделено проблеме замкнутого водооборота и отсутствию газовых выбросов.

По предлагаемому принципу нами разработаны технологии производства из древесины биофлавоноида дигидрокверцетина (ДКВ), экстракционной смолы, полисахарида арабиногалактана (АГ), кристаллической глюкозы, полифепана. Из коры лиственницы получаем антиоксидантный комплекс, пектин, парфюмерный воск и сорбенты для технических целей. Свойства и области применения этих продуктов приведены в таблице.

Расчетная добавленная стоимость перечисленных в таблице препаратов значительно превышает стоимость целлюлозных полуфабрикатов. Только реальная стоимость произведенного по технологии замкнутого цикла дигидрокверцетина и арабиногалактана из одного плотного кубометра древесины лиственницы сибирской составляет около 250-300 тыс. руб., в то время как произведенная из 1 м $^{3}$ целлюлоза может быть реализована не более чем за 10-15 тыс. руб.

Естественно, что экономическая эффективность производства перечисленных в таблице продуктов и препаратов на их основе зависит от их количественного содержания в исходной биомассе лиственницы и от примененной технологии извлечения и очистки экстрактивных веществ.

Области применения и свойства продуктов из биомассы лиственницы

\begin{tabular}{|c|c|c|}
\hline Название & Назначение & Свойства \\
\hline \multicolumn{3}{|c|}{ Древесина } \\
\hline $\begin{array}{l}\text { ДКВ-сырец } \\
\text { ДКВ 70-75\% }\end{array}$ & $\begin{array}{l}\text { Парфюмерно-косметическая } \\
\text { промышленность }\end{array}$ & $\begin{array}{c}\text { Способствует повышению защитных свойств кожи, препят- } \\
\text { ствует воздействию излучений, радиации, микробов. } \\
\text { Стабилизирует коллагеновый матрикс }\end{array}$ \\
\hline Лариксин & Сельское хозяйство & $\begin{array}{c}\text { Биологический регулятор роста и развития растений, индук- } \\
\text { тор иммунитета к грибковым заболеваниям }\end{array}$ \\
\hline $\begin{array}{l}\text { ДКВ-субстанция } \\
\text { 90-92 \% ДКВ }\end{array}$ & $\begin{array}{c}\text { Сырье для БАД } \\
\text { Добавка в пищевые продук- } \\
\text { ты }\end{array}$ & $\begin{array}{c}\text { Антиоксидантные и капилляропротекторные свойства в со- } \\
\text { четании с противовоспалительным действием }\end{array}$ \\
\hline $\begin{array}{c}\text { ДКВ } \\
\text { Таблетки ДКВ }\end{array}$ & $\begin{array}{c}\text { АФС для фармацевтической } \\
\text { продукции (медпрепарат } \\
\text { Диквертин) } \\
\text { Лекарственная форма Таб- } \\
\text { летки 0,02 г }\end{array}$ & $\begin{array}{c}\text { АФС (активная фармацевтическая субстанция для изготов- } \\
\text { ления лекарственных препаратов), ДКВ применяют в качестве } \\
\text { антиоксидантного и капилляропротекторного средства. При брон- } \\
\text { холегочных заболеваниях, в том числе при острых пневмониях, } \\
\text { хронических обструктивных бронхитах, бронхиальной астме, при } \\
\text { ишемической болезни сердца }\end{array}$ \\
\hline $\begin{array}{l}\text { Комплексы ДКВ } \\
\text { с Ca, Zn, Cu(II) }\end{array}$ & Лекарственные средства & Противовирусная, ранозаживляющая активность \\
\hline АГ сырец & $\begin{array}{c}\text { Добавка в корма с/x живот- } \\
\text { ных }\end{array}$ & $\begin{array}{c}\text { Увеличение среднесуточных привесов, снижение заболевае- } \\
\text { мости молодняка }\end{array}$ \\
\hline $\begin{array}{c}\text { АГ субстанция } \\
\text { Сырье для БАД } \\
\text { Добавка в пищевые } \\
\text { продукты }\end{array}$ & $\begin{array}{l}\text { БАДы к пище: Араглин Д; } \\
\text { Ардиксин; Сибларин +; } \\
\text { Лактовит; Овсяные пряники }\end{array}$ & Источники ДКВ, АГ (пищевых волокон), витамина С \\
\hline \multirow[t]{2}{*}{$\begin{array}{l}\text { Лигно-углеводный } \\
\text { комплекс древесины }\end{array}$} & Кристаллическая глюкоза & $\begin{array}{c}\text { Сырье для пищевой промышленности, медицины, химико- } \\
\text { фармацевтического производства }\end{array}$ \\
\hline & $\begin{array}{c}\text { Полифепан - природный } \\
\text { энтеросорбент, медпрепарат }\end{array}$ & $\begin{array}{l}\text { Эффективен при кишечных инфекциях, дисбактериозе, ал- } \\
\text { лергии, заболеваниях печени, нарушении жирового обмена }\end{array}$ \\
\hline \multicolumn{3}{|r|}{ Kopa } \\
\hline Воск & $\begin{array}{c}\text { Косметическая } \\
\text { промышленность }\end{array}$ & Бактерицидные и гидрофобные свойства \\
\hline $\begin{array}{c}\text { Антиоксидантный } \\
\text { комплекс фенольных } \\
\text { соединений }\end{array}$ & БАД «Пикнолар» & $\begin{array}{c}\text { Гепатопротектор, капилляропротектор, антиоксидантная } \\
\text { активность }\end{array}$ \\
\hline Пектины & $\begin{array}{l}\text { Пищевая промышленность, } \\
\text { фармацевтика и косметика }\end{array}$ & $\begin{array}{c}\text { Хорошие желирующие свойства, выведение из организма } \\
\text { радионуклидов }\end{array}$ \\
\hline Сорбенты & Лигноуглеводный комплекс & $\begin{array}{c}\text { Сорбент для сбора нефтепродуктов с поверхности водоемов. } \\
\text { Полифепан }\end{array}$ \\
\hline
\end{tabular}




\section{Характеристика основных продуктов из биомассы лиственницы и перспективы их применения}

Дигидрокверцетин - основная многоцелевая субстанция из древесины лиственницы, имеющая широкую направленность для создания медицинских препаратов (сердечно-сосудистых и противовирусных), БАД к пище, средство защиты растений.

Интерес к разработке новых и оптимизации существующих стереохимически чистых препаратов в медицине вызван жесткими требованиями, выдвигаемыми в настоящее время к стереоизомерам лекарственных средств. Известно, что многие синтетические и природные медицинские препараты существуют в виде двух или более пространственных изомеров, которые могут значительно различаться своим биологическим действием. Фармацевтическая промышленность, уходя от производства рацематов, акцентирует свое внимание на развитии хирально чистых S- или R-стереоизомеров лекарственных препаратов с максимальным индексом терапевтической эффективности.

Молекула ДКВ (лекарственная форма Диквертин) содержит два асимметрических атома углерода C-2 и С-3, следовательно, существует в виде 4 энантиомеров (двух пар стереоизомеров). Основным природным изомером ДКВ является транс(+)-2R,3R-изомер. Известно, что именно эти природные трансизомеры обладают наибольшей биологической активностью (рис. 1).

Выпускаемые в настоящее время промышленные образцы ДКВ отличаются по некоторым физикохимическим параметрам, несмотря на то, что сырье для их производства используется одно и то же - древесина лиственницы. Различия в характеристиках производимых образцов ДКВ можно объяснить разными технологическими условиями их производства. Любой параметр технологического процесса, особенно применение водного или безводного растворителя, может повлиять на получение продукта с разным количественным составом оптических изомеров. Соответственно, производимые образцы обладают разным уровнем антиоксидантной активности [1].

Состав энантиомеров дигидрокверцетина, производимых по технологии лаборатории химии древесины ИрИХ СО РАН (по данным ВЭЖХ): 1 (+) - 2S,3R (uис) - 0,467\%; 2 (-) - 2S,3S (транс) - 0,109\%; 3 (+) $-2 \mathrm{R}, 3 \mathrm{R}($ транс $)-98,816 \% ; 4(-)-2 \mathrm{R}, 3 \mathrm{~S}($ ичс $)-1,608 \%$.<smiles>O=C1c2c(O)cc(O)cc2C[C@H](c2ccc(O)c(O)c2)[C@@H]1O</smiles>

$2 \mathrm{R}, 3 \mathrm{R}$<smiles>O=C1c2c(O)cc(O)cc2C[C@H](c2ccc(O)c(O)c2)[C@H]1O</smiles>

$2 \mathrm{R}, 3 \mathrm{~S}$<smiles>O=C1c2c(O)cc(O)cc2C[C@H](c2ccc(O)c(O)c2)[C@H]1O</smiles>

$2 \mathrm{~S}, 3 \mathrm{~S}$<smiles>O=C1c2c(O)cc(O)cc2C[C@H](c2ccc(O)c(O)c2)[C@@H]1O</smiles>

$2 \mathrm{~S}, 3 \mathrm{R}$

Рис. 1. Структурные формулы изомеров дигидрокверцетина

Изучена протективная активность ДКВ при экспериментальной гриппозной инфекции, вызванной вирусом гриппа различных типов и подтипов А (A(H1N1), A(H5N2)) и В. Кроме того, изучено влияние стадии применения препаратов относительно начала патологического процесса на исход противовирусной терапии. Во всех случаях эффект исследованного препарата заключался в снижении смертности животных (на 25-90\%), увеличении продолжительности жизни (на 1-5 суток) и снижении титра вируса в ткани легких на 1,5-3 порядка в зависимости от дозы препарата, вируса и режима лечения [2].

Энтеровирусы представляют собой серьезную угрозу для здоровья человека. Они несут ответственность за многочисленные патологии, вплоть до болезней с летальным исходом. Из-за ограниченного количества безопасных и эффективных противовирусных препаратов существует необходимость поиска и разработки новых лекарственных средств с различными механизмами действия против энтеровирус-индуцированных патологий. 
Изучено влияние ДКВ на ход панкреатита белых мышей, вызванного вирусом Коксаки В4 (CVB4). Применение ДКВ привело к снижению дозы вируса в ткани поджелудочной железы, достигнув максимума на 5-й день. Кроме того, применение ДКВ привело к восстановлению антиоксидантной активности ткани поджелудочной железы, которая была нарушена в ходе панкреатита. Эффект ДКВ был сопоставим или превосходил эффект рибавирина. Результаты исследования показывают высокую противовирусную активность ДКВ и его многообещающий потенциал в комплексном лечении вирусного панкреатита [3].

При производстве ДКВ из древесины лиственницы в качестве побоч-

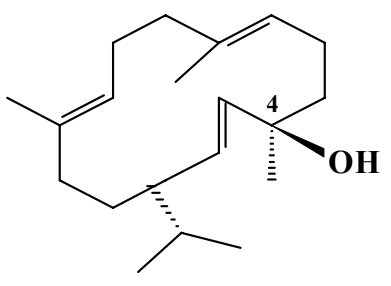

Рис. 2. Изоцемброл ного продукта выделяется значительное количество экстрактивных смолистых веществ. Суммарная фракция этих веществ по предварительным данным обладает высокой биологической активностью, проявляет ранозаживляющее и противоожоговое действие. Для создания медицинского препарата на основе этого комплекса для возможности сертификации полностью изучен его химический состав. Впервые в составе экстрактивных веществ биомассы лиственницы обнаружено дитерпеновое соединение - изоцемброл (рис. 2), обладающее свойствами гормонального регулятора роста растений. Химический состав терпеноидов древесины позволяет прогнозировать высокую биологическую активность изученного продукта и определить направление его практического использования [4].

Древесина лиственницы содержит до 20\% арабиногалактана (АГ) - водорастворимого полисахарида, извлекаемого из растительного сырья водной экстракцией [5].

Биологическое действие АГ многопланово и, вероятно, обусловлено его подобием компонентам клеточной стенки некоторых бактерий. Точно такое же соединение является основой клеточной стенки определенных видов бактерий, которые используются для стимулирования иммунной системы в ряде вакцин.

Установлено, что АГ стимулирует фагоцитарную активность макрофагов в отношении псевдотуберкулезных микробов, оказывая выраженное ингибирующее действие на размножение их внутри макрофагов [6].

В последние годы как в научной литературе, так и в официальных документах, имеющих отношение к проблемам микроэкологии желудочно-кишечного тракта человека и животных, большой интерес проявляется к пребиотическим продуктам. Пребиотики - это пищевые вещества, в том числе биоактивные пищевые волокна, избирательно стимулирующие рост и активность нормальной микрофлоры кишечника, являясь пищей для бифидобактерий и лактобацилл (пробиотиков). Арабиногалактан обладает свойствами пребиотика. Разработан ряд пребиотических пищевых добавок для поддержания роста полезных бифидобактерий и лактобацилл в желудочно-кишечном тракте человека. Являясь источником растворимых диетических волокон, АГ улучшает питание, всасывание и сохранение в здоровом состоянии желудочнокишечного тракта и может рекомендоваться как нутрицевтик или функциональная добавка к пище в ежедневной диете. Он хорошо смешивается со всеми видами пищи и напитками.

По данным доклинических исследований АГ однозначно отнесен к малотоксичным лекарственным веществам, установлен его универсальный характер безвредности. Проведенные исследования позволяют рекомендовать АГ в качестве малотоксичной и безопасной субстанции для производства лекарственных средств. Фармакологические исследования показали, что АГ также эффективен при лечении язвенных поражений желудочно-кишечного тракта, дисбактериоза, быстро снимает симптомы пищевых отравлений, .понижает уровень холестерина у страдающих гиперлипидемией. Это открывает возможности использования АГ для укрепления сердечно-сосудистой системы [7].

В областном онкологическом диспансере Иркутска проведено исследование по оценке эффективности и безопасности биокомпозита арабиногалактана с дигидрокверцетином, полученного механохимическим способом [8] в качестве вспомогательного средства при проведении химиотерапии [9]. Использование биокомпозита АГ с ДКВ (БАД Ардиксин) в сочетании со стандартной химиотерапией хорошо переносится пациентами и не приводит к увеличению токсичности лечения.

При анализе общих факторов, характеризующих состояние больных и субъективную переносимость химиотерапии, отмечаются достоверные преимущества в группе получавших комбинированное с биокомпозитом лечение, которое достоверно приводило к снижению токсичности и улучшению переносимости проводимого лечения.

Биокомпозит может назначаться пациентам, получающим химиотерапию, в качестве нутрицевтика и БАД к пище (Ардиксин) - источника пищевых волокон и дигидрокверцетина для уменьшения желудочнокишечной токсичности, улучшения самочувствия и качества жизни пациентов. 
В промышленном масштабе на базе ООО «Химия древесины» реализована экономически выгодная и экологически безопасная технология, позволяющая получать из древесины лиственницы дигидрокверцетин и арабиногалактан высокой степени чистоты [10, 11].

Показана эффективность использования этих препаратов в животноводстве, особенно при выращивании молодняка сельскохозяйственных животных. Однако высокая стоимость существенно ограничивает их масштабное применение в сельхозпредприятиях.

Рациональным решением этой проблемы явилось создание технологии получения из отходов переработки биомассы лиственницы (древесины и коры) суммарных водных экстрактов без выделения и очистки индивидуальных соединений [12].

Основой для разработки технологии явились лабораторные эксперименты, позволившие определить оптимальные параметры водной экстракции суммарного лиственничного сырья. Методами ВЭЖХ, УФ, ИК и ${ }^{13} \mathrm{C}$ ЯМР-спектроскопии установлено, что доминирующим компонентом полученных экстрактов является АГ. Кроме того, экстракты содержат ДКВ, танины и другие полифенольные соединения, пектиновые вещества, а также значительные количества биогенных минеральных элементов (кальция, калия, магния), что повышает биологическую ценность препаратов [12]. Предложенная технология позволяет использовать в качестве сырья как отходы лесозаготовки древесины лиственницы, так и смесь древесины и коры, образующуюся при ее переработке. Экстракты, полученные по разработанной технологии, можно использовать в животноводстве, как в жидком виде, так и для получения сухой биологически активной добавки к комбикормам [13].

\section{Список литературы}

1. Бабкин В.А., Остроухова Л.А., Левчук А.А., Онучина Н.А. Изучение влияния условий экстракции на выход нативного дигидрокверцетина, содержащего более $97 \%$ (+)-2R3R-mранс-изомера // Химикофармацевтический журнал. 2016. (в печати)

2. Патент 2380100 (РФ). Средство для профилактики и лечения гриппа А и В / О.И. Киселев, В.А. Бабкин, В.В. Зарубаев, Л.А. Остроухова. 27.01.2010.

3. Galochkina A., Babkin V., Ostrouhova L.,.Zarubaev V. Virus-inhibiting activity of dihydroquercetin against Coxsackievirus B4 // Arch Virol. 2016. DOI 10.1007/s00705-016-2749-3.

4. Ostroukhova L., Raldugin V., Babkin V., Onuchina N., Levchuk A. Investigation of the Chemical Composition of Larch Wood Resin // Russian Journal of Bioorganic Chemistry. 2012. Vol. 38, N7. Pp. 775-779.

5. Бабкин В.А., Остроухова Л.А., Трофимова Н.Н. Биомасса лиственницы: от химического состава до инновационных продуктов. Новосибирск, 2011. 235 с.

6. Медведева Е.Н., Бабкин В.А., Остроухова Л.А. Арабиногалактан лиственницы - свойства и перспективы использования. Обзор // Химия растительного сырья. 2003. №1. С. 27-37.

7. Отчет об экспериментальном доклиническом изучении безопасности и фармакологической активности субстанции «Арабиногалактан» / ФГУН «Институт токсикологии» ФМБА России, СПб., 2010.

8. Медведева Е.Н., Неверова Н.А. Остроухова Л.А., Бабкин В.А., Гуськов С.А., Метелева Е.С., Душкин А.В. Механокомпозиты на основе биологически активных веществ древесины лиственницы // Химия природных соединений. 2010. №2. С. 177-180.

9. Синтез нанобиокомпозита на основе дигидрокверцетина и арабиногалактана из древесины лиственницы, разработка на его основе лекарственной формы и применение для лечения онкологических заболеваний // Отчет ФГБУН ИрИХ СО РАН по Госконтракту № 2013.209792 с Министерством промышленной политики и лесного комплекса Иркутской области. 2013.

10. Бабкин В.А., Иванова С.З., Федорова Т.Е., Медведева Е.Н., Малков Ю.А., Остроухова Л.А., Трофимова Н.Н., Иванова Н.В. Научные основы технологии комплексной переработки биомассы лиственницы // Химия растительного сырья. 2007. №3. С. 9-21.

11. Патент 2256668 (РФ). Способ получения арабиногалактана / В.А. Бабкин, Л.Г. Колзунова, Е.Н. Медведева, Ю.А. Малков, Л.А. Остроухова. 20.07.2005.

12. Бабкин В.А., Малков Ю.А., Медведева Е.Н., Неверова Н.А., Левчук А.А. Технология получения биологически активных кормовых добавок из отходов переработки биомассы лиственницы // Химия в интересах устойчивого развития. 2015. Т. 23. С. 19-24.

13. Кушеев Ч.Б., Бабкин В.А., Олейников Н.А., Ломбоева С.С., Медведева Е.Н., Доржиев Б.И. Применение водного экстракта лиственницы сибирской для коррекции клинического статуса молодняка крупного рогатого скота // Достижения науки и техники АПК. 2013. №9. С. 59-61.

Поступило в редакичию 10 февраля 2016 г. 
Babkin V.A. ${ }^{l}$, Ostroukhova L.A. ${ }^{l *}$, Kopylova L.I. ${ }^{2}$ NATURAL PRODUCTS AND THEIR DERIVATIVES, OBTAINED BY TECHNOLOGY OF THE CLOSED CYCLE OF BIOMASS OF SIBERIAN LARCH PROCESSING

${ }^{I}$ Irkutsk A.E. Favorsky Institute of Chemistry SB RAS, Favorsky St., 1, Irkutsk, 664033 (Russia),

e-mail:babkin@irioch.irk.ru

${ }^{2}$ Irkutsk State University, Pedagogical Institute, Nizhniaja Naberezhnaia st., 6, Irkutsk 664003 (Russia) described.

New approach to the technology of complex larch biomass processing eliminating completely any production waste is

The obtained products of all properties and field of their application are characterized. The new data on the biological activity of the main products is cited. The possibilities of their practical application in medicine and agriculture are described.

The research is aimed at creating of larch biomass processing technology according to the principle of the closed cycle. The technology is continuous and presupposes as the raw material using in each cycle the residuum of the previous cycle without unloading from the extractor. The process is carried out in the same extractor till full using of the original wood chips.

The importance of necessary parameters determining of the technology of producing the optimum amount of dihydroquercetin (DHQ) with a maximum content of optical isomer (trans(+)-2R3R-isomer) possessing the greatest biological activity is considered.

DHQ protective activity under conditions of experimental influenza infection caused by various influenza virus types and new research on enteroviruses are described. The biological activity of larch arabinogalactan (AG) polysaccharide and new aspects of its application in medicine and agriculture are considered.

Practically important biologically active products from larch bark are fixed, their importance for medicine and the national Russian economy is demonstrated.

Keywords: larch wood, extraction, flavonoids, dihydroquercetin, stereoisomer, enterovirus, terpenoids, arabinogalactan, prebiotics, pectins.

\section{References}

1. Babkin V.A., Ostroukhova L.A., Levchuk A.A., Onuchina N.A. Khimiko-farmatsevticheskii zhurnal, 2016. (in press) (in Russ.).

2. Patent 2380100 (RU). 27.01.2010. (in Russ.).

3. Galochkina A., Babkin V., Ostrouhova L.,.Zarubaev V. Arch Virol., 2016, DOI 10.1007/s00705-016-2749-3.

4. Ostroukhova L., Raldugin V., Babkin V., Onuchina N., Levchuk A. Russian Journal of Bioorganic Chemistry, 2012, vol. 38, no. 7, pp. 775-779.

5. Babkin V.A., Ostroukhova L.A., Trofimova N.N. Biomassa listvennitsy: ot khimicheskogo sostava do innovatsionnykh produktov. [Biomass larch: from chemistry to innovative products]. Novosibirsk, 2011, 235 p. (in Russ.).

6. Medvedeva E.N., Babkin V.A., Ostroukhova L.A. Khimiia rastitel'nogo syr'ia, 2003, no. 1, pp. 27-37. (in Russ.).

7. Otchet ob eksperimental'nom doklinicheskom izuchenii bezopasnosti $i$ farmakologicheskoi aktivnosti sub-stantsii «Arabinogalaktan». FGUN «Institut toksikologii» FMBA Rossii. [A report on the pilot study of the preclinical safety and pharmacological activity of the sub-station "arabinogalactan." FSIS 'Institute of Toxicology »FMBA of Russia]. St. Petersburg, 2010. (in Russ.).

8. Medvedeva E.N., Neverova N.A. Ostroukhova L.A., Babkin V.A., Gus'kov S.A., Meteleva E.S., Dushkin A.V. Khimiia prirodnykh soedinenii, 2010, no. 2, pp. 177-180. (in Russ.).

9. Sintez nanobiokompozita na osnove digidrokvertsetina i arabinogalaktana iz drevesiny listvennitsy, raz-rabotka na ego osnove lekarstvennoi formy i primenenie dlia lecheniia onkologicheskikh zabolevanii. Otchet FGBUN IrIKh SO RAN po Goskontraktu № 2013.209792 s Ministerstvom promyshlennoi politiki i lesnogo kompleksa Irkutskoi oblasti. [Synthesis of nano-bio-composite based on Dihydroquercetin and arabinogalactan from larch wood, time-based processing on its formulation and use in the treatment of cancer. Report FGBUN o irixo SB RAS under Government Contracts number 2013.209792 with the Ministry of Industrial Policy and the forest complex of the Irkutsk region]. 2013. (in Russ.).

10. Babkin V.A., Ivanova S.Z., Fedorova T.E., Medvedeva E.N., Malkov Iu.A., Ostroukhova L.A., Trofimova N.N., Ivanova N.V. Khimiia rastitel'nogo syr'ia, 2007, no. 3, pp. 9-21. (in Russ.).

11. Patent 2256668 (RU). 20.07.2005. (in Russ.).

12. Babkin V.A., Malkov Iu.A., Medvedeva E.N., Neverova N.A., Levchuk A.A. Khimiia v interesakh ustoichivogo razvitiia, 2015, vol. 23, pp. 19-24. (in Russ.).

13. Kusheev Ch.B., Babkin V.A., Oleinikov N.A., Lomboeva S.S., Medvedeva E.N., Dorzhiev B.I. Dostizheniia nauki $i$ tekhniki APK, 2013, no. 9, pp. 59-61. (in Russ.).

Received February 10, 2016

Revised March 14, 2016

\footnotetext{
* Corresponding author.
} 